\title{
Pelatihan Penguatan Peran Badan Permusyawaratan Rakyat Nagari (BPRN) dalam Mendukung Penyelenggaraan Pemerintahan Nagari di Nagari Sumanik Kabupaten Tanah Datar
}

\author{
Ria Ariany, Desna Aromatica, Hendri Koeswara, Ilham Aldelano Azre, Kusdarini, \\ Muhammad Ichsan Kabullah, Misnar Sitriwanti, Roni Ekha Putera, Rozidateno P \\ Hanida, Syamsurizaldi, Wewen Kusumi Rahayu, dan Yoserizal \\ Fakultas Ilmu Sosial dan Ilmu Politik, Universitas Andalas, Kampus Limau Manis, Padang, 25163. Indonesia \\ E-mail: riaariany@soc.unand.ac.id
}

Keywords: consultative body, duties and functions, village law

Kata Kunci:

Badan

Permusyawaratan Desa, tugas dan fungsi, UU Desa

\begin{abstract}
After the enactment of the Village Law which is full of various new policies, it also has implications for the Village Consultative Body (BPD) with changes in the position, duties, functions and authority of the BPD. One of them is the issuance of Permendagri No. 110/2016 concerning BPD, and most recently in the context of West Sumatra the issuance of the Regional Regulation of West Sumatra Province No 7/2018 concerning Nagari. This Perda is claimed to be the first indigenous village regulation in Indonesia that wants to show the existence of Nagari "Asli" vis a vis with the implementation of modern village government in the implementation of public services. On the other hand, the weak role and function of BPD in running village government still occurs, including Nagari Sumanik. This dedication activity was to provide an understanding of the shifting position of BPRN; increase the understanding of BPRN members regarding their roles, functions, duties and authorities; and strengthening the role of BPRN in supporting the administration of the nagari government. The method of implementing community service included 3 (three) stages, namely; 1) Preparation; 2) Implementation; and, 3) Program evaluation or reflection on activities. Not all Regencies / Cities have responded to the policies of the Nagari Government in West Sumatra, including the Tanah Datar District, so this service activity is important for BPRN Sumanik, where not all members have a government background in strengthening their capacity to carry out their duties and functions and anticipate changes in policy.
\end{abstract}
ABSTRAK
Pasca diberlakukannya UU Desa yang sarat akan ragam keluarnya kebijakan baru, berimplikasi juga kepada Badan Permusyawaratan Desa (BPD) dengan perubahan atas kedudukan, tugas, fungsi dan wewenang BPD. Salah satunya adalah keluarnya Permendagri No 110/2016 tentang BPD, dan yang terkini dalam konteks Sumatera Barat keluarnya Perda Provinsi Sumatera Barat No 7/2018 tentang Nagari. Perda ini diklaim sebagai perda desa adat pertama di Indonesia yang ingin menunjukkan eksistensi Nagari "Asli" vis a vis dengan penyelenggaraan pemerintahan desa modern dalam pelaksanaan pelayanan publik. Di sisi lain, lemahnya peran dan fungsi BPD dalam menjalankan pemerintahan desa masih terjadi, tak terkecuali Nagari Sumanik. Kegiatan pengabdian ini untuk memberikan pemahaman tentang pergeseran kedudukan BPRN; meningkatkan pemahaman anggota BPRN akan peran, 
fungsi, tugas, serta kewenangannya; dan penguatan peran BPRN dalam mendukung penyelenggaraan pemerintahan nagari. Metode pelaksanaan pengabdian kepada masyarakat meliputi 3 (tiga) tahapan, yaitu; 1) Persiapan; 2) Pelaksanaan; dan, 3) Evaluasi program atau refleksi kegiatan. Tetapi fenomena yang terjadi adalah belum semua Kabupaten/Kota merespon kebijakan Pemerintahan Nagari di Sumatera Barat, termasuk juga Kabupaten Tanah Datar, sehingga kegiatan pengabdian ini penting bagi BPRN Sumanik. Disamping itu, dikarenakan bahwa tidak semua anggota memiliki latar belakang pemerintahan dalam penguatasan kapasitas mereka untuk menjalankan tugas dan fungsi, serta antisipasi terhadap perubahan kebijakan.

\section{PENDAHULUAN}

Ambiguitas UU No. 32/2004 yang berupaya menyempurnakan kekurangan dari UndangUndang No. 22/1999 meletakkan posisi Desa yang berada di bawah Kabupaten tidak koheren dan kongruen dengan apa yang diatur dalam UU No. 32/2004 yang justru mengakui dan menghormati kewenangan asli yang berasal dari hak asal-usul. Widjaja (2003), mengungkapkan desa adalah kesatuan masyarakat hukum yang mempunyai susunan asli berdasarkan hak asalusul yang bersifat istimewa. Permasalahan ini jika ditelusuri lebih jauh tentang keberadaan desa-desa di Indonesia, desa merupakan daerah otonom tertua di Republik ini. Mengacu pada pendapat Susanti dan Setiajid (2018), terdapat lebih kurang 250 Zelfbesturende landscappen dan Volksgemeenschappen dalam Negara Indonesia, seperti desa di Jawa dan Bali, Nagari di Minangkabau, Dusun dan Marga di Palembang, Gamping di Aceh dan sebagainya. Hal tersebut merujuk pada ungkapan dari Kartohadikoesoemo (1964) yang menyatakan, bahwa desa didirikan sebelum lahirnya daerah koordinasi yang lebih besar dan sebelum lahirnya negaranegara (kerajaan). Oleh karena itu maka desa mempunyai hak otonomi penuh. Akan tetapi, diantara ketidaksempurnaan UU No. 22/1999 tersebut, ia telah meletakkan BPD sebagai unsur lembaga legislatif yang tidak dikenal selama ini dalam UU No. 5/1979 (Zainal, 2008).

Kenyataan yang ada tentang Desa semenjak orde baru hingga era reformasi yang berlangsung seperti sekarang ini, otonomi desa lebih dimaknai sebagi bentuk penyeragaman, artinya desa tidak diberikan ruang untuk memfasilitasi dan mewadahi potensi keanekaragaman yang dimiliki dan sebagai implikasinya desa tidak lagi diimajinasikan memiliki keistimewaan dan orisinilitasnya yang beragam, sehingga desa kehilangan ciri dan karakteristiknya. Sebagai satuan pemerintahan terkecil, pemerintahan desa dijalankan oleh Kepala Desa dan Badan Permusyawaratan Desa (BPD). Kepala desa bertugas menyelenggarakan pemerintahan desa, melaksanakan pembangunan desa, pembinaan kemasyarakatan desa dan pemberdayaan masyarakat desa. Berdasarkan UU No. 6/2014 tentang Desa, BPD mempunyai fungsi membahas dan menyepakati Rancangan Peraturan Desa bersama kepala desa, menampung dan menyalurkan aspirasi masyarakat desa dan melakukan pengawasan kinerja kepala desa seperti yang terdapat dalam UU Desa tersebut tentang fungsi BPD yang diatur lebih lanjut melalui Permendagri No. 110/2016 tentang BPD.

Hal subtantif lainnya dari UU Desa adalah memuat perubahan kedudukan, tugas, fungsi dan wewenang kepala desa dan BPD, dimana kepala desa tidak lagi bertanggung jawab kepada BPD. Hubungan kerja antara kepala desa dan BPD bersifat hubungan kemitraan, konsultasi dan koordinasi, seperti Kepala Desa dan BPD membahas dan menyepakati bersama Peraturan Desa. Kepala Desa dan BPD memprakarsai perubahan status desa menjadi kelurahan melalui musyawarah desa. Kepala Desa memberikan laporan penyelenggaraan pemerintahan secara tertulis kepada BPD, dimana BPD memberitahukan kepada kepala desa mengenai akan berakhirnya masa jabatan kepala desa secara tertulis yakni enam bulan sebelum masa jabatannya berakhir. Kajian Pamuji dkk (2017) bahwa BPD bukan lagi unsur dari Pemerintah Desa. Permasalahan lain tentang hubungan Pemerintah Desa dan BPD ini, yakni Kepala Desa mengajukan Rancangan Anggaran Pendapatan dan Belanja Desa dan memusyawarahkannya secara bersama dengan BPD. Hal lain yang tidak kalah pentingnya pengaturan tentang kepala 
desa dan BPD membahas bersama pengelolaan kekayaan milik desa atau yang disebut juga dengan aset desa.

Perubahan hubungan antara Kepala Desa dengan BPD, disamping memperkuat tetapi justru memperlemah fungsi BPD, seperti pertanggungjawaban kepala desa yang tidak lagi disampaikan kepada BPD, melainkan kepada bupati melalui camat. Kepala desa hanya wajib memberikan laporan keterangan penyelenggaraan pemerintahan secara tertulis kepada BPD. Sama halnya dengan substansi dari Permendagri No. 110/2016 tentang BPD yang tidak berbeda jauh dengan UU Desa, mempertegas kembali BPD sebagai lembaga pelaksana fungsi pemerintahan yang anggotanya merupakan wakil penduduk desa berdasarkan keterwakilan wilayah dan ditetapkan secara demokratis. Fenomena ini yang akan diatur lebih lanjut untuk mengakomodir adanya kearifan lokal dalam praktik bernagari ke dalam Perda Provinsi Sumatera Barat No. 7/2018 tentang Nagari. Dalam isi Perda ini menyebutkan bahwa Kerapatan Adat Nagari (KAN) adalah lembaga yang merupakan perwujudan permusyawaratan perwakilan tertinggi dalam penyelenggaraan Pemerintahan Nagari yang keanggotaannya terdiri dari perwakilan ninik mamak dan unsur alim ulama Nagari, unsur cadiak pandai, unsur Bundo Kandung, dan unsur parik paga dalam Nagari yang bersangkutan sesuai dengan adat Salingka Nagari. Fenomena yang menarik adalah, berdasarkan Perda provinsi Sumatera Barat No. 7/2018 tentang Nagari, bahwa tugas KAN disamping mengawasi jalannya penyelenggaraan pemerintahan nagari oleh Kapalo Nagari dan menyusun peraturan nagari bersama Kapalo Nagari. Kebijakan ini mencoba mengatur fungsi budgeting yang dimiliki oleh KAN untuk membahas dan menyepakati Rancangan Peraturan Nagari tentang Anggaran Pendapatan dan Belanja Nagari. Hal ini merupakan upaya agar pengelolaan dana desa semakin akuntabel maka diperlukan mekanisme pengawasan yang salah satu aktornya adalah BPD. Hal yang berbeda dengan kebijakan negara beberapa waktu yang lalu dengan melibatkan K/L dalam usaha preventif penyimpangan keuangan desa, padahal BPD merupakan garda terdepan untuk hal tersebut di Desa.

Implementasi UU No. 6/2014 yang mengatur wewenang, hak dan kewajiban desa tersebut memunculkan banyak harapan, tantangan, dan kekhawatiran yang bermuara pada tuntutan terhadap meningkatnya kapasitas penyelenggara pemerintahan desa baik pemerintah desa maupun BPD (PKDOD, 2015). Berdasarkan observasi atas persoalan peranan BPD (di Nagari Sumanik Kecamatan Salipaung Kabupaten Tanah Datar menggunakan nama Badan Perwakilan Rakyat Nagari) dalam penyelenggaran Pemerintahan Nagari bahwa fungsi BPRN lebih didominasi fungsi pengawasan, dibandingkan fungsi legislasi (menyepakati Rancangan Perdes dan menampung aspirasi masyarakat), sedangkan berdasarkan Perda Provinsi Sumatera Barat No. 7/2018 dimana keterlibatan KAN sebagai representasi BPD di Nagari mempunyai fungsi pengawasan dan budgeting. Fenomena ini sejalan dengan hasil Kajian dari Roza dan Arliman (2017) bahwa vitalnya peran BPD adalah dalam fungsi pengawasan keuangan desa.

Tranformasi BPD atau BPRN menjadi KAN berdasarkan regulasi terbaru ini, belum membumi pelaksanaannya termasuk juga di Nagari Sumanik yang merupakan salah satu dari 6 (enam) nagari yang ada di Salimpaung yang merupakan salah satu tuo (tua) di lingkungan Pemerintahan Tuanku Titah Sungai Tarab. Kondisi tersebut tidak jauh berbeda dengan desa lain hasil penelitian Anwar (2015) di Kecamatan Pringgarata, Kabupaten Lombok Tengah yang menunjukkan sejumlah faktor yang menyebabkan minimnya pelaksanaan fungsi BPD antara lain anggaran operasional untuk melakukan tugas dan fungsi sangat sedikit dibandingkan dengan operasional Kepala Desa, dan hal inipun terjadi di Nagari Sumanik. Begitupun juga dengan hasil kajian Setyaningrum dan Wisnaeni (2019) yang menunjukkan bahwa di Desa Plumbon fungsi BPD tidak berjalan dengan baik. Kajian yang memperlihatkan lemahnya fungsi BPD seperti yang ditemukan oleh Romli dan Nurlia (2017) yang menemukan empat kelemahan BPD dalam pelaksanaan fungsi yaitu kurangnya kapasitas SDM BPD, sarana pendukung kerja BPD kurang memadai, dan pendapatan BPD yang minim, dan belum terdapat kebijakan yang menguatkan posisi BPD dalam pelaksanaan fungsinya. Kajian lain yang menemukan kelemahan BPD adalah yang dilakukan oleh Susanti dan Setiajid (2018) bahwa keterbatasan SDM menjadi penyebab ketidakefektifan BPD dalam penyelenggaraan pemerintahan desa. 
Fenomena ini pun terjadi di Nagari Sumanik, dimana beragamnya latar belakang anggota BPRN dan banyak yang tidak memahami tentang pemerintahan desa menjadikan fungsi BPD menjadi tidak optimal. Berdasarkan analisis situasi yang telah dikemukakan, maka tujuan kegiatan penguatan kapasita anggota BPRN dalam penyelenggaraan pemerintahan nagari adalah: 1) Memberikan pemahaman pergeseran kedudukan BPRN pasca dikeluarkannya pelbagai kebijakan menyangkut BPD; 2) Meningkatkan pemahaman anggota BPRN Sumanik agar memahami dan menyadari peran, fungsi, tugas, serta kewenangannya; dan 3) Penguatan peran BPRN dalam mendukung penyelenggaraan pemerintahan nagari di Nagari Sumanik Kecamatan Salimpaung Kabupaten Tanah Datar Tahun 2019. Tidak efektifnya pelaksanaan fungsi legislasi atau pembuatan peraturan desa karena minimnya pemahaman, keterampilan dan SDM yang dimiliki serta kurang tanggapnya Pemerintah dan Pemerintah Daerah khususnya yang menangani Pemerintahan Desa terhadap pembinaan dan pemberdayaan kelembagaan Desa khususnya Badan Permusyawaratan Desa. Berdasarkan hal tersebut di atas, Program Studi Administrasi Publik FISIP Universitas Andalas perlu untuk melakukan penguatan kapasitas Anggota BPRN Nagari Sumanik.

\section{METODE}

Metode pelaksanaan pengabdian kepada masyarakat, yaitu: pertama, persiapan. Tahap persiapan meliputi: 1) administrasi; 2) koordinasi dengan pihak khalayak sasaran (anggota BPRN se-Nagari Sumanik), Pemerintah Kecamatan Salimpaung, Dinas Pemberdayaan Masyarakat dan Nagari Kabupaten Tanah Datar, dan Dinas Pemberdayaan Masyarakat Provinsi Sumatera Barat; 3) penyiapan materi kegiatan pengabdian; 4) persiapan narasumber; 5) penyiapan waktu dan tempat pelaksanaan kegiatan; dan 5) pengecekan terakhir. Kedua, pelaksanaan. Pelaksanaan kegiatan dalam bentuk sosialisasi dengan judul: Penguatan Peran Badan Permusyawaratan Rakyat Nagari (BPRN) dalam Mendukung Penyelenggaraan Pemerintahan Nagari di Nagari Sumanik Kecamatan Salimpaung Kabupaten Tanah Datar dengan khalayak sasaran seluruh anggota BPRN se-Nagari Sumanik, sebagai upaya meningkatkan pemahaman anggota BPRN terhadap peran, fungsi, tugas, serta kewenangannya agar terwujud hubungan BPRN dan pemerintah desa yang harmonis dan efektif dalam penyelenggaraan pemerintahan. Ketiga, evaluasi program (refleksi). Evaluasi program yang dimaksud meliputi: evaluasi pemahaman peserta tentang tugas, fungsi, wewenang BPRN. Dilanjutkan dengan penguatan peran BPRN melalui: 1) Peningkatan kompetensi anggota BPD terkait tugas, fungsi, dan wewenang BPRN; 2) Perbaikan metode perekrutan. Metode perekrutan diupayakan lebih transparan, akuntabel, dan memperhatikan keterwakilan perempuan; dan 3) Meningkatkan animo masyarakat untuk bersedia menjadi anggota BPRN dengan memberikan kesadaran kepada masyarakat pentingnya peran BPRN dalam meningkatkan kemandirian, kesejahteraan, dan demokratisasi di tingkat desa. Sebagaimana yang dikemukakan oleh Suseno (2016) memilih dan dipilih menjadi Anggota BPD merupakan sejumlah hak masyarakat.
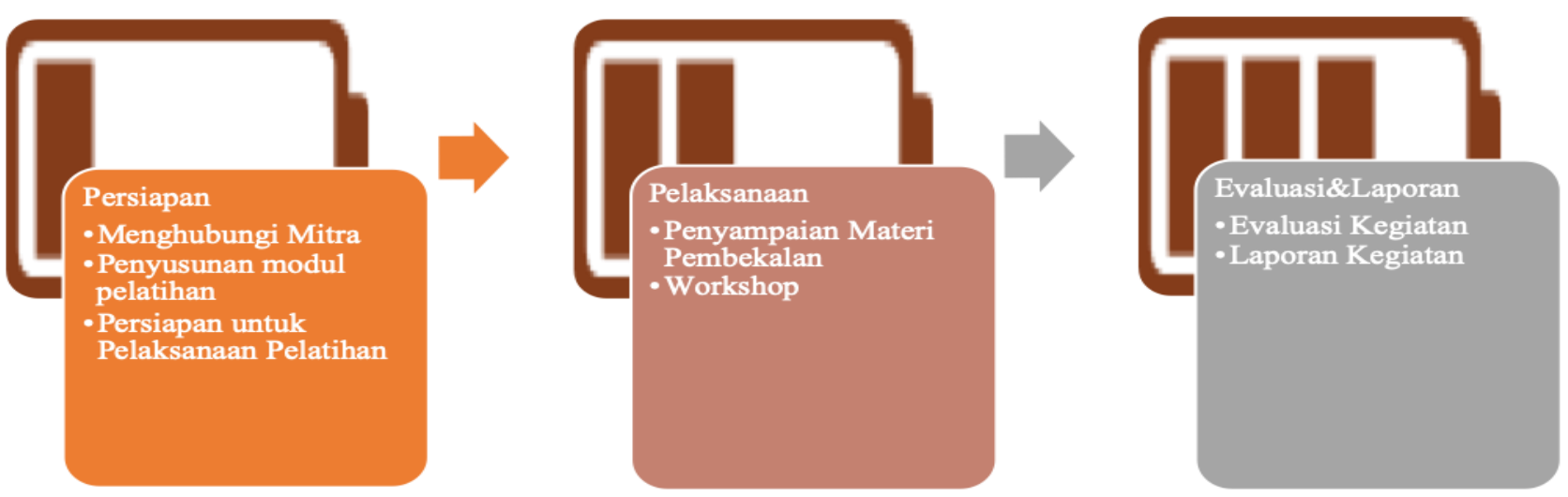

Gambar 1. Langkah Pelaksanaan Kegiatan Pengabdian Masyarakat 


\section{HASIL DAN PEMBAHASAN}

Sama halnya dengan pemerintah dan pemerintah daerah (provinsi dan kabupaten/kota), penyelenggaraan pemerintahan desa atau nagari di Sumatera Barat juga dilengkapi dan dijalankan oleh lembaga eksekutif dan lembaga legislatif. Lembaga eksekutif dipimpin oleh kepala desa atau wali nagari di Sumatera Barat dan perangkatnya, dan lembaga legislatif dipegang oleh Badan Permusyawaratan Desa (BPD) atau di Kabupaten Tanah Datar disebut dengan Badan Permusyawaran Rakyat Nagari (BPRN). Tetapi selama ini yang terjadi proses penyelenggaraan pemerintahan desa lebih terfokus pada lembaga pemerintah desa yaitu kepala desa dan perangkatnya terutama dalam pembinaan dan pengawasan. Padahal dalam substansi yang dibawa sejak keluarnya UU No 22/1999 terdapat eksistensi BPD yang secara tegas juga menyatakan bahwa yang menjalankan fungsi pemerintahan desa itu bukan hanya Kepala Desa, tetapi jugaBPD atau disebut BPRN di Kabupaten Tanah Datar.

Kegiatan ini dimulai dengan pemberian materi dan pendalaman pemahaman terhadap substansi dari UU No 6 Tahun 2014 tentang Desa, utamanya tentang BPD yang merupakan lembaga yang melaksankan fungsi pemerintahan desa yang anggotanya merupakan wakil dari penduduk desa berdasarkan keterwakilan wilayah dan ditetapkan secara demokratis. Pemerintahan desa akan berjalan efektif apabila unsur-unsur atau lembaga-lembaga penyelanggara pemerintahan desa dapat berjalan dengan baik. Adapun yang menjadi fungsi BPD berdasarkan Permendagri No. 110/2016 adalah sebagai berikut:

1. Membahas dan menyepakati Rancangan Peraturan Desa bersama Kepala Desa;

2. Menampung dan menyalurkan aspirasi masyarakat Desa; dan

3. Melakukan pengawasan kinerja Kepala Desa.

Sedangkan yang menjadi tugas dari Anggota BPD terdapat 13 (tiga belas) poin penting dalam Permendagri No. 110/2016 tersebut, lebih jelasnya adalah sebagai berikut:

1. Menggali aspirasi masyarakat;

2. Menampung aspirasi masyarakat;

3. Mengelola aspirasi masyarakat;

4. Menyalurkan aspirasi masyarakat;

5. Menyelenggarakan musyawarah BPD;

6. Menyelenggarakan musyawarah Desa;

7. Membentuk panitia pemilihan Kepala Desa;

8. Menyelenggarakan musyawarah Desa khusus untuk pemilihan Kepala Desa antarwaktu;

9. Membahas dan menyepakati rancangan Peraturan Desa bersama Kepala Desa;

10. Melaksanakan pengawasan terhadap kinerja Kepala Desa;

11. Melakukan evaluasi laporan keterangan penyelenggaraan Pemerintahan Desa;

12. Menciptakan hubungan kerja yang harmonis dengan Pemerintah Desa dan lembaga Desa lainnya; dan

13. Melaksanakan tugas lain yang diatur dalam ketentuan

Jika dibandingkan dengan Pemerintah Desa, BPD pada umumnya masih dinilai lemah, belum dapat sepenuhnya menjalankan tugas dan fungsinya dengan baik sesuai dengan aturan perundang-undangan yang berlaku. Begitu juga halnya yang terjadi dengan BPRN Sumanik, dari hasil penyampaian materi dan diskusi dengan anggota BPRN Sumanik memiliki latar belakang yang beragam yang membuat tugas dan fungsi sebagai lembaga penyeimbang Pemerintah Nagari belum berjalan optimal. Dampaknya adalah BPD tidak mempunyai pengaruh yang cukup signifikan terhadap peningkatan kinerja pemerintah desa. Apalagi salah satu fungsi legislatif yang terkait dengan eksekutif adalah mengontrol eksekutif dalam hal ini pemerintah desa dalam arti menjaga supaya semua tindakan pemerintah desa sesuai dengan dokumen perencanaan dan penganggaran atau kebijakan yang dikeluarkan oleh desa yang telah ditetapkan. Untuk itu, juga disampaikan materi tentang substansi fungsi dari pengawasan yang mesti dilakukan oleh Anggota BPRN Sumanik, tentang pengelolaan desa yang demokratis, terpapar pada Gambar 2. 


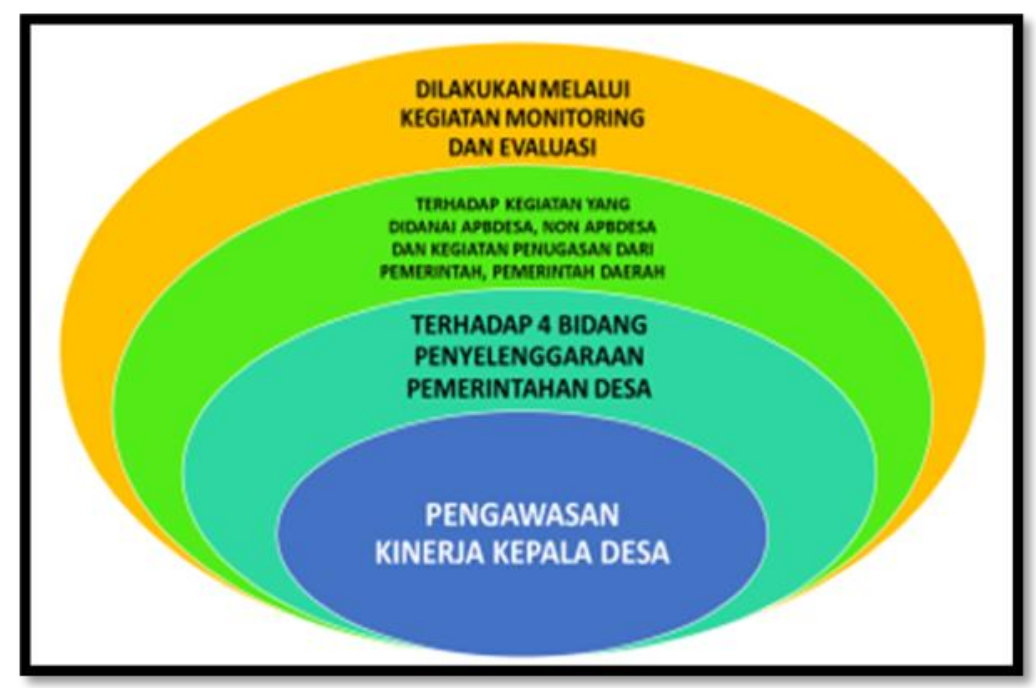

Gambar 2. Kerangka Pengawasan Kinerja Pemerintah Desa oleh BPD

Di sisi yang lain, BPRN tidak maksimal dalam menjalankan tugas dan fungsi mereka dalam melaksanakan tugas yang diemban. Disamping ketidakberdayaan dalam pemahaman akan tugas dan fungsi BPRN, masyarakat juga tidak mempunyai pengetahuan yang cukup tentang tugas dan fungsi BPRN sehinga keberadan BPRN tidak dipandang oleh masyarakat, dan menyebabkan timbulnya anggapan negatif terhadap BPRN. Permasalahan lain yang terjadi adalah BPRN dinilai tidak bekerja oleh Masyarakat. Padahal dalam penyelenggaraan pemerintahan diperlukan keseimbangan kekuatan (check and balance) antara kepala desa dan perangkatnya sebagai lembaga yang menjalakan fungsi eksekutif dengan Badan Permusyawaratan Desa (BPD) sebagai lembaga yang menjalankan fungsi legislatif. Hasil identifikasi yang dilakukan oleh tim pengabdian Jurusan Administrasi Publik FISIP Universitas Andalas dalam kajian yang dilakukan masih ditemukan beberapa kelemahan pada lembaga BPD di Sumatera Barat, diantaranya adalah:

1. Lemahnya fungsi legislasi yaitu dalam membahas dan menyepakati Rancangan Peraturan Desa (Perdes) bersama kepala desa. Dalam hal fungsi membahas dan menyepakati rancangan Peraturan Desa (Perda) bersama kepala desa, BPD baru pada tahapan membahas dan menyepakati Perdes tentang APBDes dan RPJMDes yang regular harus ada.

2. Lemahnya BPD dalam menampung dan menyalurkan aspirasi masyarakat desa. Dalam melaksanakan fungsi menampung dan menyalurkan aspirasi masyarakat desa, BPD baru dapat menyelenggarakan Musrenbang (Musyawarah Rencana Pembangunan Desa) setiap tahun, padahal misalnya saja dalam pembahasan RPJMDesa misalnya, BPD punya hak untuk memberikan pandangan terhadap rancangan RPJMDesa.

3. Lemahnya BPD dalam melakukan pengawasan kinerja kepala desa. Dalam hal melakukan pengawasan terhadap kinerja kepala desa, kontrol yang dilakukan telah sesuai dengan fungsi BPD, tetapi tidak sampai detail karena seringkali diingatkan oleh pemerintah desa, hal tersebut bukanlah bagian dari tugas BPD padahal sebaliknya.. Misalnya ketika terdapat pembagunan sarana fisik, kemudian dalam pelaksanaanya dikontrol oleh BPD apakah dilaksankan sesuai dengan dokumen perencanaan yang ada.

Kondisi yang dihadapi oleh BPRN Sumanik dalam menjalankan tugas pokok dan fungsifungsi tersebut, diakibatkan oleh faktor-faktor berikut ini:

1. Kapasitas Sumber Daya Manusia yang menjadi anggota BPD lemah;

2. Sarana pendukung kerja BPD yang kurang memadai;

3. Program dan kegiatan yang ada dalam APBDes seringkali tidak diprioritaskan untuk peningkatan kapasitas anggota BPD; dan

4. Kebijakan yang ada belum memperkuat kelembagaan BPD sebagai bagian dari pemerintahan desa (masih dalam proses formulasi kebijakan di Kabupaten Tanah Datar). 
Regulasi untuk persyaratan menjadi calon anggota BPD adalah sebagai berikut:

1. Bertakwa kepada Tuhan Yang Maha Esa;

2. Memegang teguh dan mengamalkan Pancasila, melaksanakan Undang-Undang Dasar Negara Republik Indonesia Tahun 1945, serta mempertahankan dan memelihara keutuhan Negara Republik Indonesia dan Bhinneka Tunggal Ika;

3. Berusia paling rendah 20 (dua puluh) tahun atau sudah/pernah menikah;

4. Berpendidikan paling rendah tamat sekolah menengah pertama atau sederajat;

5. Bukan sebagai perangkat Pemerintah Desa;

6. Bersedia dicalonkan menjadi anggota BPD;

7. Wakil penduduk Desa yang dipilih secara demokratis; dan

8. Bertempat tinggal di wilayah pemilihan.

Berdasarkan data yang ada, anggota BPRN Sumanik terdiri atas 9 orang, 1 (orang) dilantik menjadi Sekretaris Nagari, sementara penggantinya belum dilantik saat ini yang masih menunggu SK penggantian dari Pemerintah Kabupaten Tanah Datar. Kurang maksimalnya tugas dan fungsi anggota BPRN dengan adanya penguatan kapasitas yang difasilitasi oleh Jurusan Administrasi Publik yang juga menghadirkan narasumber dari Pemerintah Provinsi Sumatera Barat merupakan salah satu cara agar SDM anggota BPRN dapat menjalankan fungsi pemerintahan desa sebagaimana mestinya. Dukungan anggaran untuk kegiatan anggota BPRN telah coba diperbaiki dalam Tahun Anggaran 2020 dengan telah dianggarkannya beberapa kegiatan yang mendukung pelaksanaan tugas anggota BPRN, yang terjadi selama ini adalah ketidaksamaan paham dalam mendistribusikan kegiatan yang diperuntukkan untuk anggota BPRN dalam APBNag Sumanik. Untuk menyikapi kelemahan yang ada tersebut, pemerintah kabupaten tengah mempersiapkan regulasi untuk mengantisipasi perubahan kebijakan sebagai konsekuensi atas terbitnya Perda Provinsi tentang Pemerintahan Nagari. Kegiatan ini bukan tanpa hambatan, terlambatnya pencairan anggaran pengabdian, kesibukan staf pengajar dosen yang akan melaksanakan rutinitas lainnya dan kesediaan narasumber dari Pemerintah Provinsi Sumatera Barat menjadikan kegiatan ini sedikit terlambat dari rencana yang telah dirancang sebelumnya.

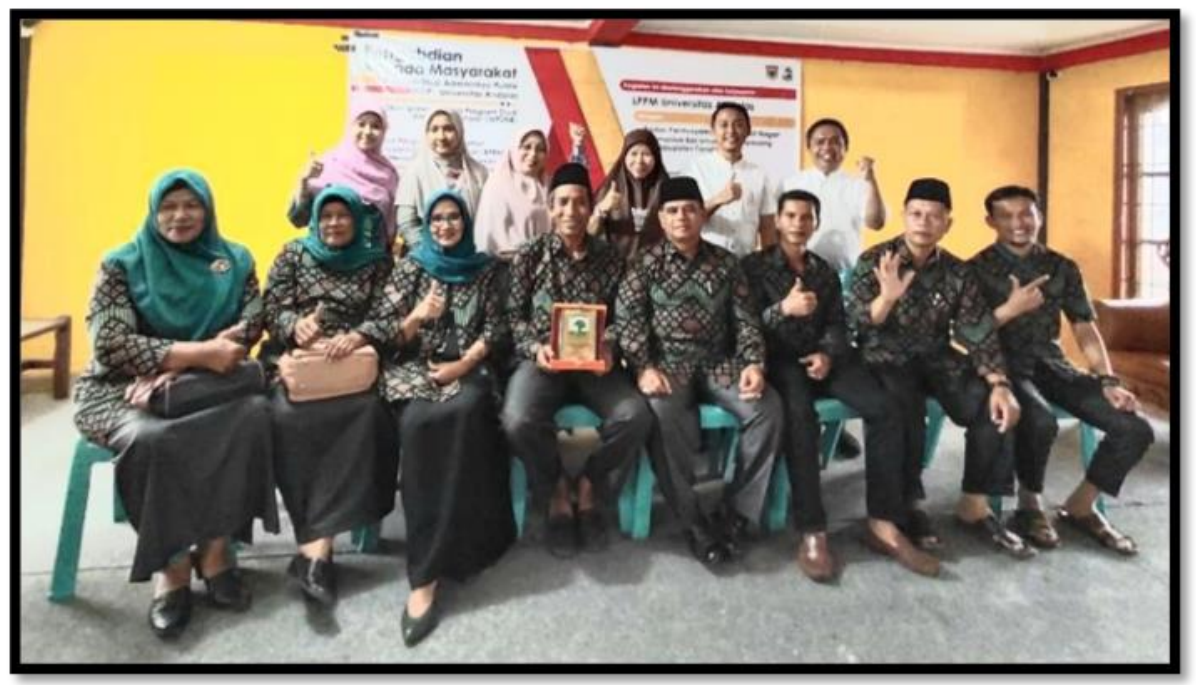

Gambar 3. Tim Pelaksana Kegiatan Pengabdian Program Studi Administrasi Publik

\section{KESIMPULAN}

Perhatian terhadap BPD sebagai bagian dari pemerintahan desa tidak dapat dinafikkan sebagai sebuah kunci keberhasilan pemerintahan desa. Penguatan lembaga BPD dapat dilakukan percepatan keluarnya kebijakan dalam hal ini pemerintah Kabupaten Tanah Datar yang dapat mendorong BPD dapat bekerja melaksanakan fungsinya sesuai Undang-Undang Desa dan 
mengemban tugas penting dalam mengimplementasikan Perda Provinsi tentang Pemerintahan Nagari. Adanya pelatihan atau bimbingan teknis penguatan kapasitas anggota BPD secara intensif oleh pemerintah atau pemerintah daerah agar anggota BPD benar-benar memiliki kemampuan dalam menjalankan fungsinya sehingga penyelenggaraan pemerintahan dan pelaksanaan pembangunan desa berjalan efektif yang pada gilirannya dapat mempercepat terjadinya kesejahtraan dan kemajuan masyarakat desa. Aktivitas pengabdian yang dilakukan oleh Jurusan Administrasi Publik juga berkontribusi dalam menutupi kekurangan aktivitas pemerintah dalam penguatan kapasitas BPD. Akan tetapi hal tersebut sangat memiliki keterbatasan dalam sisi anggaran dan perencanaan, padahal BPD merupakan salah satu fokus dari kajian administrasi publik yang masih memerlukan fasilitasi dan sumbangan keilmuan secara teoritik dan empirik agar pemerintahan nagari berjalan dengan baik. Sehingga segala kekurangan atau kelemahan dari BPD yang ada saat ini seperti dari lemahnya kapasitas SDM, minimnya anggaran untuk BPD, kebijakan yang kurang memperhatikan BPD dapat tertutupi. Untuk itu terdapat beberapa rekomendasi yang dapat dihasilkan yaitu kolaborasi antara perguruan tinggi, pemerintah kabupaten dan pemerintah nagari untuk mengidentifikasi penguatan kapasitas yang dilakukan sehingga kegiatan yang dilakukan betul-betul mencerminkan kebutuhan dari Pemerintah Nagari sebagai yang dikenai impak kegiatan pengabdian.

\section{UCAPAN TERIMA KASIH}

Dalam kesempatan ini, penulis menyampaikan ucapan terima kasih kepada LPPM Universitas Andalas yang telah berkenan memberikan kesempatan melakukan kegiatan pengabdian masyarakat kepada Program Studi Administrasi Publik FISIP Universitas Andalas, Pemerintahan Kabupaten Tanah Datar, dan Pemerintahan Nagari Sumanik khususnya BPRN Sumanik, dan tidak lupa untuk Dinas Pemberdayaan Masyarakat Desa dan Nagari Pemerintah Provinsi Sumatera Barat.

\section{DAFTAR PUSTAKA}

Anwar, K. 2015. 'Hubungan kerja antara kepala desa dengan Badan Permusyawaratan Desa (BPD) menurut Undang-Undang Nomor 6 Tahun 2014 tentang Desa', Jurnal IUS, 3(8), hal.207.

H.A.W. Widjaja. 2003. Otonomi desa merupakan otonomi yang asli, bulat dan utuh. Jakarta: Raja Grafindo Persada.

Kartohadikoesomo, Soetardjo. 1984. Desa. Jakarta: PT Balai Pustaka.

Kementerian Keuangan Republik Indonesia. 2017. Buku pintar dana desa: Dana desa untuk kesejahteraan rakyat.

Pamuji, Kadar; Nasihudin, Abdul Aziz; Adhanariswari, Riris; Supriyanto. 2017. Pengembangan model peran Badan Permusyawaratan Desa (BPD) dalam penyelenggaraan pemerintahan desa di Desa Banjarpanepen Kecamatan Sumpiuh Kabupaten Banyumas. Prosiding seminar Nasional Pengembangan Sumber Daya Pedesaan dan Kearifan Lokal Berkelanjutan VII. Purwokerto.

Perda Provinsi Sumatera Barat No. 7 Tahun 2018 tentang Nagari.

Permendagri No.110 Tahun 2016 tentang Badan Permusyawaratan Desa (BPD). 
PKDOD. 2015. Implementasi UU Desa dan Tantangan Pengembangan Kapasitas Pemerintah Desa. Policy Brief No 3/PKDOD.

Susanti, M. Herna dan Setiajid. 2018. 'Penguatan peran Badan Permusyawaratan Desa (BPD) dalam mendukung sinergitas penyelenggaraan pemerintahan desa di Kabupaten Semarang Tahun 2018', Jurnal Integralistik, 2(XXIX), hal.208-216.

Suseno dan D. Aji. 2016. 'Analisis perencanaan pembangunan desa berbasis Undang-Undang Desa No 6 Tahun 2014 di Kecamatan Gunungpati Kota Semarang', Jurnal STIE Semarang, 2 (2), hal.122-137.

Setyaningrum, Christine Ayu dan Wisnaeni, Fifiana. 2019. 'Pelaksanaan fungsi Badan Permusyawaratan Desa terhadap penyelenggaraan pemerintahan desa', Jurnal Pembangunan Hukum Indonesia, 1 (2), hal.168-170.

Romli, Omni dan Nurlia, Elly. 2017. 'Lemahnya Badan Permusyawaratan Desa (BPD) dalam melaksanakan fungsi pemerintahan desa', Jurnal Ilmu Pemerintahan, 3 (1), hal.36-54.

Roza, Darmini dan Arliman S, Laurensius. 'Peran Badan Permusyawaratan Desa di dalam pembangunan desa dan pengawasan keuangan desa', Jurnal Ilmu Hukum, 4(3), hal.606-624.

Undang-Undang No. 6 Tahun 2014 tentang Desa.

Zainal. 2008. 'Dinamika kebijakan pemerintahan desa di Indonesia dari masa ke masa (studi Tahun 1979-2015). Jurnal TAPIs, 12(1), hal.19-36. 